\title{
IMPACT OF FLIPPED CLASSROOM
}

\section{INDIRA PRIYADARSHINI}

Associate Professor, Department of English, Vidya Jyoti Institute of Technology, Telangana, India

\section{ABSTRACT}

This study explores the "flipped" classroom and its outcomes on student learning. The flipped classroom is a sort of preparing in which students learn new substance in the midst of out-of-class-time instead of the customary study hones that are frequently given, which opens up class time for activities, problem-solving, and diverse kind of instruction. In the midst of this examination, a flipped classroom was executed in an English classroom for I Year B. Tech understudies. Data was accumulated from student's grades, a classroom discussion, and my own notes from teaching. The results show that some potential favorable advantages of the flipped classroom make it a sort of preparing that teachers should not to disregard.

KEYWORDS: Flipped Classroom, Project-Based Learning, Problem-Solving, Prerecorded \&Conventional Classroom

Received: May 17, 2018; Accepted: Jun 07, 2018; Published: Jun 30, 2018; Paper Id.: IJELAUG201801

\section{INTRODUCTION}

A present pattern in the instruction group has instructors flipping out the country over. This pattern is known as the "flipped classroom" or "transformed classroom." A flipped classroom, as its name recommends, is where the address and homework have been switched. As such, the training issues typically finished at home are dealt with in the classroom, and the immediate guidelines regularly given amid class time is given as homework through video addresses, perusing assignments, or some other direct direction conveyance technique. Notwithstanding, this thought has developed into a more nuanced type of instruction.

The principle expectation of this investigation was to examine the adequacy of a customary address based classroom versus an altered flipped classroom instruction. In the conventional classroom, students were given lectures in the classrooms and they were discretionary. There were no tests or question answer sessions. Students in the flipped classroom were required to watch the prerecorded addresses previously going to the class. There were later presented to test and question-answer sessions.

\section{SURVEY OF LITERATURE}

The utilization of the flipped classroom can possibly be a successful and advantageous strategy for instruction. Supplanting direct guideline (the express scripted introduction or conveyance of data or an undertaking) from the class time with video addresses saw outside of the classroom takes into account more class-time to be utilized for dynamic learning. Dynamic learning can incorporate exercises, discourse, understudy made substance, free critical thinking, request based learning, and venture based learning (Bergmann, Overmyer, and Wilie, 2012). This utilization of class-time can make a classroom situation which utilizes collective and constructivist getting the hang of; mixing with the immediate guideline utilized outside the classroom (Tucker 2012). Constructivist learning happens when understudies pick up information through direct individual encounters, for example, exercises, 
ventures, and exchanges. (Ultanir, 2012). The recurrence of these individual encounters can be expanded in a flipped classroom using exercises, making understudies who are dynamic students (learning by taking part in investigation, blend, and assessment), as opposed to aloof students (learning by the assimilation of data from hearing, seeing, and perusing) (Minhas, Ghosh, and Swanzy, 2012; Sams, 2013). The aloof learning of a flipped classroom occurs amid the video addresses outside of class, arranging for in-class time for dynamic learning (Tucker, 2012). Dynamic learning has been found to deliver preferable evaluations over uninvolved learning (Minhas, Ghosh, and Swanzy, 2012). Community oriented learning happens when at least two individuals pick up something together, considering each other responsible for their learning (Roberts, 2004). Community learning can make understudies who are more put resources into their own particular getting the hang of, craving to prevail keeping in mind the end goal to meet the desires of one's associates (Roberts, 2004). Through gathering exercises, discourses, and gathering critical thinking, a flipped classroom can accomplish an abnormal state of community-oriented learning.

\section{METHODOLOGY}

Two segments of B. Tech I year understudies of EEE branches are taken as a test of my investigation to check the adequacy of the customary classroom and modified flipped classroom. In the conventional classroom for EEE A understudies live addresses were given whereas in the changed flipped classroom i. e. EEE B, Prerecorded addresses were given to the understudies and they were made a request to watch the addresses previously going to the class. In any case, understudies of both branches were furnished with same address notes before class. Understudies of the flipped classroom have tests and question-answer session.

Understudies in the changed flipped class were not given live addresses but rather were made a request to watch recorded addresses from the customary course before class. Addresses were strengthened with either homework issues that were later talked about in class or few inquiries that were controlled toward the start of the class. Issues were not taken a shot at as gatherings in class, but rather each class was given homework or test as a major aspect of the exchange in lieu of a conventional address. Test and homework's were reviewed.

Understudies in the two segments were given indistinguishable example exam addresses that were talked about in an hour long audit session before the exam. The general viability of these diverse learning methodologies was fundamentally surveyed by making understudies to answer similar sorts of tests.

\section{RESULTS}

The execution of the understudies of the flipped classroom was superior to the execution of the understudies who had experienced conventional educating. Most understudies concurred that they watched the address recordings before coming to class. Understudies felt that the tests given toward the start of every session spurred them for more prominent pre-class readiness. Numerous understudies detailed that flipped classroom display was one of a kind as far as they can tell and most had a moderately low level of beginning eagerness for this organization. Be that as it may, in course of time numerous understudies revealed expanded excitement after the experience however, a couple of understudies communicated disappointment.

Numerous understudies favored exchange amid class session. A few understudies announced that pre-class planning enabled them to think of more keen inquiries to be talked about $n$ the class. This procedure additionally helped them to be in the know regarding the material and made concentrate less demanding for the exam. 


\section{CONCLUSIONS}

This examination was made to assess the adequacy of a customary address based class versus a changed flipped classroom. Inside a similar gathering, the flipped classroom show seemed to have the beneficial outcome on general understudy execution. The essential goal of flipped classroom demonstrate is to concentrate on dynamic pre-class readiness, in this way permitting classroom time to concentrate on issues and dialog, including more dynamic learning. In some flipped variant, the classroom session would involve group-based learning in which the educator assumes the part of a facilitator instead of a teacher.

My underlying knowledge with an adaptation of flipped classroom display was sure. I opine that such a model could be utilized by the whole staff with adequate specialized help to encourage conveying a prerecorded address to understudies. In light of understudy input, it is opined that utilization of homework and in-class tests was a basic persuading factor that adds to the understudy's cooperation in classroom discourse. This model likewise gives the instructor more class time to strengthen on imperative focuses or draw in then in critical thinking works out. At last, it is opined that flipped classroom display is a very powerful intends to enhance understudy's execution.

\section{REFERENCES}

1. http://scholarworks.bgsu.edu/honorsprojects]

2. Szparagowski, Raymond, "The Effectiveness of the Flipped Classroom" (2014). Honors Projects. Paper 127.

3. Bergmann, Overmyer, \& Wilie. (2012). The Flipped Class: What it is and What it is Not. The Daily Riff.

4. Strayer, J. F. (2008). The effects of the classroom flip on the learning environment: A comparison of learning activity in a traditional classroom and a flip classroom that used an intelligent tutoring system. Dissertation Abstracts International Section A, 68,

5. https://www.iitbombayx.in/dashboard

6. Pedagogy on online and blended teaching learning process, IITBombayX.FDP201x 
